\title{
ASSOCIATION OF BLOOD PRESSURE IN ADULTS WITH SELECTED ANTHROPOMETRIC PARAMETERS AND CRP: A HOSPITAL BASED CROSS SECTIONAL STUDY
}

\author{
Katta Subraya Prakash Rao1, Peraje Vasu Dinesh ${ }^{2}$
}

${ }_{1}^{1}$ Assistant Professor, Department of General Medicine, KVG Medical College, Sullia, Dakshina Kannada, Karnataka. ${ }^{2}$ Assistant Professor, Department of Community Medicine, KVG Medical College, Sullia, Dakshina Kannada, Karnataka.

\begin{tabular}{l} 
ABSTRACT \\
\hline BACKGROUND \\
Hypertension is a major public health problem and a known risk factor for cardiovascular disease. Epidemiological studies \\
from different populations have reported significant association between different anthropometric indicators and hypertension.
\end{tabular}

\section{AIMS AND OBJECTIVES}

The present study was carried out to examine the relationship between C-reactive protein, different anthropometric indices and blood pressure in adults.

\section{MATERIALS AND METHODS}

This is a hospital-based cross-sectional study done among 250 patients over 40 years of age, attending Medicine OPD of a tertiary care institution selected based on their willingness and eligibility to participate. Anthropometric measurements, blood pressure examination and laboratory investigations were done and used for this study.

\section{RESULTS}

Increased blood pressure was found in both obese and non-obese individuals. BMI, waist circumference, neck circumference, sagittal abdominal diameter and CRP was higher in hypertensive males than normotensives and it was statistically significant. Karl Pearson correlation showed that BMI, WC, HC, NC, SAD and CRP had a positive correlation with systolic and diastolic blood pressure and it was found to be statistically significant.

\section{CONCLUSION}

In this study CRP, SAD, HC, WC and NC showed a positive correlation with both systolic and diastolic blood pressure, which means that WC and SAD can be used to get information about visceral obesity in an individual. This also suggests that decrease in intra-abdominal fat could decrease the blood pressure.

\section{KEYWORDS}

Hypertension, Anthropometry, CRP.

HOW TO CITE THIS ARTICLE: Rao KSP, Dinesh PV. Association of blood pressure in adults with selected anthropometric parameters and CRP: a hospital based cross sectional study. J. Evolution Med. Dent. Sci. 2016;5(51):3283-3288, DOI: $10.14260 /$ jemds/2016/761

\section{INTRODUCTION}

High Blood Pressure (BP) is a major public health problem in India and its prevalence is rapidly increasing among both urban and rural population.1,2 The prevalence of hypertension in India ranges between $20-40 \%$ in urban adults and $12-17 \%$ among rural adults 3 . Reducing blood pressure can decrease cardiovascular risk. Many modifiable and non-modifiable factors are associated with blood pressure such as age, gender, body size, body mass index, physical activity, diet and stress levels. However, the main influencing factors for increased blood pressure as evidenced by many studies are obesity, metabolic syndrome and familial factors of hypertension. 4

Anthropometry is the most common and accessible technique used to diagnose abdominal obesity in the field.

Financial or Other, Competing Interest: None.

Submission 06-05-2016, Peer Review 03-06-2016,

Acceptance 09-06-2016, Published 25-06-2016.

Corresponding Author:

Dr. Katta Subraya Prakash Rao,

Assistant Professor,

Department of General Medicine,

KVGMCH, Kurunjibhag,

Sullia, Dakshina Kannada-574327,

Karnataka.

E-mail: ksprkrao0@gmail.com

DOI: $10.14260 /$ jemds $/ 2016 / 761$
The common anthropometric measurements in adults are height, weight, waist circumference, hip circumference and thus the BMI and waist hip ratio. Other than these common measurements, Sagittal Abdominal Diameter (SAD) and neck circumference have also been used in certain studies as a measure of fat deposit in the body. $5,6,7$

The association of excess body weight with elevated BP has been demonstrated in several studies. ${ }^{8}$ But there are only a few studies, which associate the not so commonly used anthropometric parameters like sagittal abdominal diameter, neck circumference and C-Reactive Protein (CRP) with elevated BP.

The objective of this research paper was to study the relationship between selected common and not so common anthropometric parameters such as waist circumference, sagittal abdominal diameter, neck circumference and CRP among hypertensives and non-hypertensive individuals.

\section{MATERIALS AND METHODS}

A cross-sectional study was carried out among patients who visited medicine OPD of a tertiary care teaching hospital in South India between October 2014 and April 2015.

Sample size was calculated based on a pilot study, which showed that the proportion of hypertensives was $20 \%$ and using the formula $n=V / d^{2}$ where $V=P_{1}\left(1-P_{1}\right)+P_{2}\left(1-P_{2}\right)$ 
sample size was calculated to be 123 , which was rounded off to 125 . Thus, 125 hypertensives and 125 non-hypertensives were recruited for this study.

All individuals aged 40 years or older attending the outpatient department during the study period were recruited consecutively based on their willingness and eligibility to participate in the study.

\section{Inclusion Criteria}

Individuals with 40 years of age and above who were not on any medications except anti-hypertensives who are willing to be part of our study.

\section{Exclusion Criteria}

Subjects with spinal deformity, abdominal tumour, lump, significant ascites, pregnant females, pathological diseases (Cancer, thyroid neck swelling, insufficient renal and chronic inflammatory pathologies) and in whom anthropometry measurements were not feasible.

Patients with conditions known to be associated with increased CRP levels like acute renal failure, bacterial infections, meningitis, smoking, trauma, etc. and patients with severe hepatocellular impairment were excluded from the study.

\section{Data Collection}

Detailed history was taken.

\section{DEFINITION OF RISK FACTORS.9,10,11,12,13}

\section{Measurement of Blood Pressure}

Blood pressure was measured thrice with five-minute interval on the left arm using appropriate cuff size and standard mercury sphygmomanometer. The average of three readings was considered for analysis. Systolic BP of $>140$ $\mathrm{mmHg}$ and/or diastolic BP of $>90 \mathrm{mmHg}$ and/or those on medication for BP were considered as hypertensives.

\section{Measurement of Weight}

Weight was measured with minimum clothing using SECA digital weighing scale (Nearest to $0.1 \mathrm{~kg}$ ).

\section{Measurement of Height}

Height was measured using anthropometric rod with the subject made to stand erect on a flat surface (Without footwear) with feet together.

\section{Calculation of BMI}

BMI was calculated as weight $(\mathrm{Kg})$ divided by height in meters square. BMI of less than 18.5 was considered underweight, values between 18.5 and 24.99 was considered normal, between 25 and 29.99 was considered pre-obese and BMI more than or equal to 30 was considered obese.

\section{Measurement of Waist Circumference}

Waist Circumference (WC) was measured according to WHO criteria in standing position after normal expiration, midway between the lower rib margin and the iliac crest.

\section{Measurement of Hip Circumference}

The anatomical place used for assessment of HC was the height of the greater trochanter as recommended by the WHO.

\section{Calculation of Waist Hip Ratio}

WHR was calculated by dividing waist circumference in $\mathrm{cms}$ by hip circumference in cms. Waist hip ratio of 0.81 and more in females and 0.88 and more in males was considered as having abdominal obesity.

\section{Measurement of Sagittal Abdominal Diameter}

SAD or "Supine Abdominal Height" was measured after a normal expiration to nearest $0.1 \mathrm{~cm}$ in supine position with straight legs on a firm examination table using a ruler and water level at the level of iliac crest (L4-5) without clothes. SAD cut-offs were taken as $\geq 22 \mathrm{~cm}$ in men and $\geq 20 \mathrm{~cm}$ in women.

\section{Measurement of Neck Circumference}

Neck circumference was measured to within $1 \mathrm{~mm}$ by using a tape measure. Participants were asked to stand erect with their head positioned in the Frankfort horizontal plane. The superior border of a tape measure was placed just below the laryngeal prominence and applied perpendicular to the long axis of the neck. Neck circumference of $\geq 37 \mathrm{cms}$ in male and $\geq 34 \mathrm{cms}$ in female was considered abnormal.

\section{Relevant Laboratory Work-Up was also Done}

1. Serum CRP levels.

2. Lipid profile: Serum total cholesterol, HDL, LDL and triglycerides.

3. Fasting and postprandial plasma glucose.

The level of C-reactive protein was determined by latexenhanced nephelometry method having sensitivity $0.5-320$ $\mathrm{mg} / \mathrm{L}$. This method could not detect CRP levels of $<0.5 \mathrm{mg} / \mathrm{L}$. As a result, persons with CRP levels of $<0.5 \mathrm{mg} / \mathrm{L}$ were classified as having "undetectable" CRP levels. (AGAPPE, MISPA-I Autoanalyser). Lipid profile by AGAPE-MISPA Nano Autoanalyser. (TC-cholesterol oxidase method, TG-glycerol 3phosphate oxidase method, HDL-C by direct qualitative determination, LDL-C by calculation). Blood sugars were determined by Glucose oxidase method.

\section{Ethics Statement}

The protocol was approved by the Institutional Ethical Committee and informed consent was obtained from all participants.

\section{Statistical Analysis}

The data was entered in Microsoft Excel 2007 and SPSS version 17 was used for analysis.

\section{RESULTS}

Of the 250 subjects studied, 180 were males and 70 were females; $36.4 \%$ of them belonged to $40-50$ years followed by $29.2 \%$ belonging to $51-60$ years, $25.6 \%$ belonged to $61-70$ years, $6.8 \%$ belonged to $71-80$ years, $1.6 \%$ belonged to $81-90$ years and $0.4 \%$ belonged to $91-100$ years. The mean age of the study participants was $56.36 \pm 10.93$ as shown in Table 1 .

Among the study participants, 125 were hypertensive and the rest were normal with respect to blood pressure. The mean systolic blood pressure was $133.68 \pm 22.22$ and mean diastolic blood pressure was $83.73 \pm 12.62$ as shown in Table 1. 
With regards to the nutritional status of the study participants according to BMI, $14.8 \%$ were underweight, $58.8 \%$ were normal, $17.6 \%$ were pre-obese and $8.8 \%$ were obese as seen in Table 2. The mean BMI of the study participants was $23.09 \pm 4.97$ as seen in Table $1 ; 80 \%$ of the total males studied and $86 \%$ of the total females studied were obese with respect to WHR as seen in Table 2. The mean WHR was $0.93 \pm 0.08$ as seen in Table 1 .

\begin{tabular}{|c|c|c|c|c|c|}
\hline Variable & \begin{tabular}{|c} 
Total \\
Mean \pm \\
SD \\
$\mathbf{N}=\mathbf{2 5 0}$
\end{tabular} & \begin{tabular}{|c|} 
Male \\
Mean \pm \\
SD \\
$\mathbf{N}=180$
\end{tabular} & $\begin{array}{c}\text { Female } \\
\text { Mean } \pm \\
\text { SD } \\
\mathrm{N}=70\end{array}$ & $\begin{array}{c}\mathbf{t} \\
\text { Value }\end{array}$ & $\begin{array}{c}P \\
\text { Value }\end{array}$ \\
\hline $\begin{array}{c}\text { Age } \\
\text { (years) }\end{array}$ & $\begin{array}{c}56.36 \pm \\
10.93\end{array}$ & \begin{tabular}{|c|}
$55.53 \pm$ \\
10.82
\end{tabular} & \begin{tabular}{|c|}
$58.49 \pm$ \\
11.0
\end{tabular} & 1.9331 & 0.0544 \\
\hline $\begin{array}{l}\text { Height } \\
\text { (cms) }\end{array}$ & $\begin{array}{c}162.86 \pm \\
8.96\end{array}$ & $\begin{array}{c}166.13 \pm \\
7.57\end{array}$ & $\begin{array}{c}154.44 \pm \\
6.47\end{array}$ & 11.3988 & $0.0001^{*}$ \\
\hline $\begin{array}{l}\text { Weight } \\
\text { (kgs) }\end{array}$ & $\begin{array}{c}61.20 \pm \\
13.50\end{array}$ & \begin{tabular}{|c|}
$63.12 \pm$ \\
13.10
\end{tabular} & \begin{tabular}{|c|}
$56.27 \pm$ \\
13.35
\end{tabular} & 3.6925 & $0.0003^{*}$ \\
\hline $\begin{array}{c}\text { BMI } \\
(\mathrm{Kg} / \mathrm{m} 2)\end{array}$ & $\begin{array}{c}23.09 \pm \\
4.97 \\
\end{array}$ & $\begin{array}{c}22.89 \pm \\
4.77 \\
\end{array}$ & $\begin{array}{c}23.60 \pm \\
5.47 \\
\end{array}$ & 1.0132 & 0.3119 \\
\hline $\begin{array}{c}\text { Waist } \\
\text { circumference } \\
\text { (cms) }\end{array}$ & $\begin{array}{c}84.06 \pm \\
12.77\end{array}$ & $\begin{array}{c}84.58 \pm \\
12.50\end{array}$ & $\begin{array}{c}82.74 \pm \\
13.42\end{array}$ & 1.0235 & 0.3071 \\
\hline \begin{tabular}{|c|} 
Hip \\
Circumference \\
(cms) \\
\end{tabular} & $\begin{array}{c}90.69 \pm \\
10.69\end{array}$ & \begin{tabular}{|c|}
$89.93 \pm$ \\
9.87
\end{tabular} & $\begin{array}{c}92.65 \pm \\
12.43\end{array}$ & 1.8141 & 0.0709 \\
\hline \begin{tabular}{|c|} 
Neck \\
circumference \\
$(\mathrm{NC})$
\end{tabular} & $\begin{array}{c}35.76 \pm 3 \\
60\end{array}$ & $\begin{array}{c}36.15 \pm \\
3.56\end{array}$ & $\begin{array}{c}34.76 \pm \\
3.53\end{array}$ & 2.7784 & $0.0059 *$ \\
\hline $\begin{array}{l}\text { Sagittal } \\
\text { Abdominal } \\
\text { diameter } \\
(\mathrm{cms})\end{array}$ & $\begin{array}{c}22.0 \pm \\
4.58\end{array}$ & $\begin{array}{c}22.34 \pm \\
4.74\end{array}$ & $\begin{array}{c}25.16 \pm \\
4.08\end{array}$ & 4.3846 & $0.0001^{*}$ \\
\hline $\begin{array}{c}\text { Waist Hip } \\
\text { Ratio }\end{array}$ & $\begin{array}{c}0.93 \pm \\
0.08\end{array}$ & $\begin{array}{c}0.94 \pm \\
0.08\end{array}$ & $\begin{array}{c}0.89 \pm \\
0.07\end{array}$ & 4.5892 & $0.0001^{*}$ \\
\hline $\begin{array}{l}\text { Systolic Blood } \\
\text { Pressure } \\
\text { (mm Hg) }\end{array}$ & $\begin{array}{c}133.68 \pm \\
22.22\end{array}$ & $\begin{array}{c}132.62 \pm \\
21.02\end{array}$ & $\begin{array}{c}136.4 \pm \\
25.02\end{array}$ & 1.2085 & 0.2280 \\
\hline $\begin{array}{l}\text { Diastolic } \\
\text { Blood } \\
\text { Pressure } \\
\text { (mm Hg) }\end{array}$ & $\begin{array}{c}83.73 \pm \\
12.62\end{array}$ & $\begin{array}{c}83.36 \pm \\
12.71\end{array}$ & $\begin{array}{c}84.69 \pm \\
12.41\end{array}$ & 0.7478 & 0.4553 \\
\hline \multicolumn{6}{|c|}{$\begin{array}{c}\text { Table 1: Demographic, Anthropometric and Blood } \\
\text { Pressure Characteristics of the Study Participants by } \\
\text { Sex }\end{array}$} \\
\hline
\end{tabular}

*Statistically significant

With regards to the neck circumference, $46.7 \%$ of the males had a neck circumference $\geq 37 \mathrm{cms}$ and $62.9 \%$ of the females had a neck circumference $\geq 34 \mathrm{cms}$ as seen in Table 2 . The mean neck circumference was $35.76 \pm 3.60$ as seen in Table 1.

$47.77 \%$ of the males had sagittal abdominal diameter $\geq 22$ cms and $35.71 \%$ of females had SAD $\geq 20 \mathrm{cms}$ as seen in Table 2.

It was noted that hypertension was not solely restricted to the overweight and obese individuals, but also seen in study subjects who had a normal BMI, waist circumference, waist-hip ratio, neck circumference and sagittal abdominal diameter as seen in Table 2 and 3.

\begin{tabular}{|c|c|c|c|}
\hline \multirow[t]{2}{*}{ Variables } & \multicolumn{2}{|c|}{ Males } & \multirow{2}{*}{$\begin{array}{c}\text { Chi } \\
\text { square }\end{array}$} \\
\hline & $\begin{array}{l}\text { Hypertensives } \\
\text { No. (\%) }\end{array}$ & $\begin{array}{l}\text { Normotensives } \\
\text { No. (\%) }\end{array}$ & \\
\hline \multicolumn{4}{|c|}{ BMI } \\
\hline$<18.50$ & $10(5.56)$ & $20(11.11)$ & \multirow{4}{*}{$\begin{array}{c}\mathrm{df}=1 \\
\mathrm{p}=0.003^{*}\end{array}$} \\
\hline $18.50-24.99$ & $45(25)$ & $60(33.33)$ & \\
\hline $25.00-29.99$ & $19(10.56)$ & $12(6.67)$ & \\
\hline$\geq 30$ & $12(6.67)$ & $2(1.11)$ & \\
\hline \multicolumn{4}{|c|}{ Waist Circumference } \\
\hline$<85 \mathrm{cms}$ & $35(19.44)$ & $62(34.44)$ & \multirow[b]{2}{*}{$\begin{array}{c}\mathrm{df}=1 \\
\mathrm{p}=0.001^{*}\end{array}$} \\
\hline$\geq 85 \mathrm{cms}$ & $51(28.33)$ & $32(17.78)$ & \\
\hline \multicolumn{4}{|c|}{ Waist Hip Ratio } \\
\hline$<0.88$ & $15(8.33)$ & $21(11.67)$ & \multirow{2}{*}{$\begin{array}{c}\mathrm{df}=1 \\
\mathrm{p}=0.412\end{array}$} \\
\hline$\geq 0.88$ & $71(39.44)$ & $73(40.56)$ & \\
\hline \multicolumn{4}{|c|}{ Neck Circumference } \\
\hline$<37 \mathrm{cms}$ & $34(18.89)$ & $62(34.44)$ & \multirow{2}{*}{$\begin{array}{c}\mathrm{df}=1 \\
\mathrm{p}=0.000^{*}\end{array}$} \\
\hline$\geq 37 \mathrm{cms}$ & $52(28.89)$ & $32(17.78)$ & \\
\hline \multicolumn{4}{|c|}{ Sagittal Abdominal Diameter } \\
\hline$<22 \mathrm{cms}$ & $31(17.22)$ & $63(35)$ & \multirow{2}{*}{$\begin{array}{c}\mathrm{df}=1 \\
\mathrm{p}=0.000^{*}\end{array}$} \\
\hline$\geq 22 \mathrm{cms}$ & $55(30.56)$ & $31(17.22)$ & \\
\hline \multicolumn{4}{|c|}{$\begin{array}{l}\text { Table 2: Prevalence of Overweight/Obesity as per } \\
\text { Different Anthropometric Indicators in Males }\end{array}$} \\
\hline
\end{tabular}

*Statistically significant

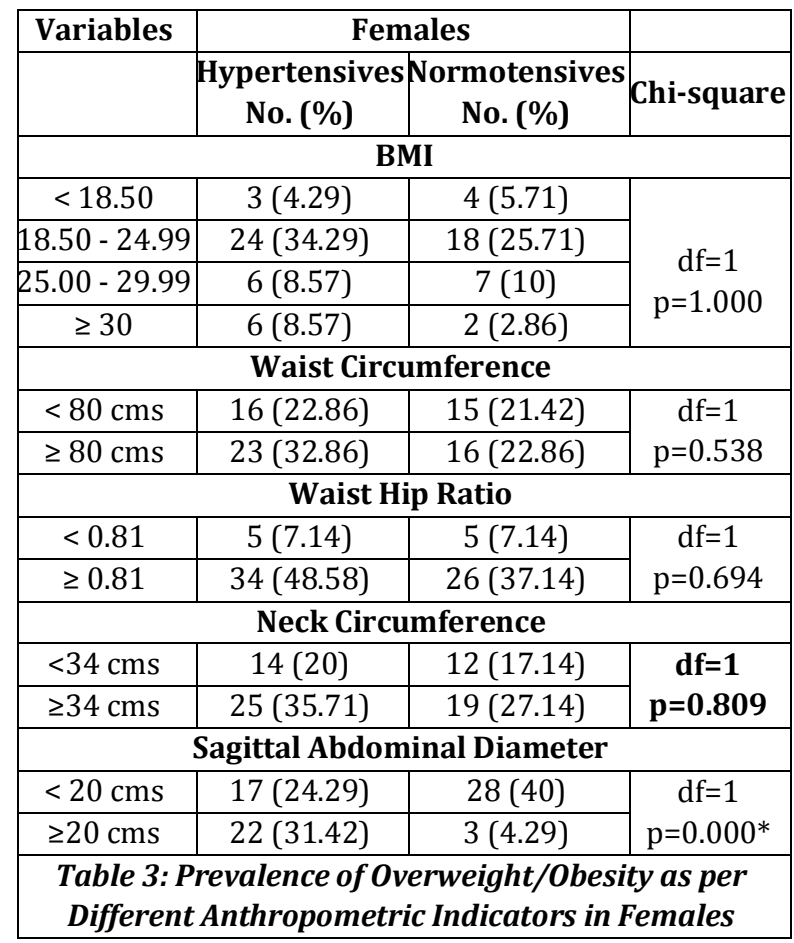

*Statistically significant

It was seen from Table 4 that the mean BMI, waist circumference, neck circumference, sagittal abdominal diameter and CRP was higher in hypertensive males than normotensives and it was statistically significant. But only CRP values were significantly higher when hypertensive females were compared with the normotensive females. 


\begin{tabular}{|c|c|c|c|c|c|c|}
\hline \multirow[b]{2}{*}{ Risk Factors } & \multicolumn{2}{|c|}{ Male } & \multirow[b]{2}{*}{ p value } & \multicolumn{2}{|c|}{ Female } & \multirow[b]{2}{*}{ p value } \\
\hline & $\begin{array}{c}\text { Normotensives } \\
\text { Mean } \pm \text { SD }\end{array}$ & $\begin{array}{l}\text { Hypertensives } \\
\text { Mean } \pm \text { SD }\end{array}$ & & $\begin{array}{c}\text { Normotensives } \\
\text { Mean } \pm \text { SD }\end{array}$ & $\begin{array}{l}\text { Hypertensives } \\
\text { Mean } \pm \text { SD }\end{array}$ & \\
\hline BMI & $21.57 \pm 3.57$ & $24.33 \pm 5.46$ & $<0.0001^{*}$ & $23.08 \pm 5.00$ & $24.02 \pm 5.85$ & 0.4793 \\
\hline WC & $81.04 \pm 10.69$ & $88.44 \pm 13.24$ & $<0.0001^{*}$ & $81.62 \pm 13.18$ & $83.62 \pm 13.71$ & 0.5395 \\
\hline WHR & $0.93 \pm 0.07$ & $0.95 \pm 0.08$ & 0.0754 & $0.89 \pm 0.08$ & $0.89 \pm 0.07$ & 1.0000 \\
\hline $\mathrm{NC}$ & $35.13 \pm 3.06$ & $37.28 \pm 3.73$ & $<0.0001^{*}$ & $34.19 \pm 3.76$ & $35.21 \pm 3.31$ & 0.2321 \\
\hline SAD & $20.99 \pm 3.89$ & $23.81 \pm 5.15$ & $<0.0001^{*}$ & $21 \pm 3.58$ & $21.28 \pm 4.48$ & 0.7778 \\
\hline CRP & $1.69 \pm 1.54$ & $2.77 \pm 1.93$ & $<0.0001^{*}$ & $1.46 \pm 1.02$ & $2.85 \pm 1.75$ & $0.0002^{*}$ \\
\hline
\end{tabular}

*Statistically significant

Karl Pearson correlation was used to measure and analyse the degree of relationship between the chosen cardiovascular risk factors with systolic and diastolic blood pressures. Among those risk factors which were considered in this study BMI, waist circumference, hip circumference, neck circumference, sagittal abdominal diameter, total cholesterol and CRP levels had a positive correlation with systolic and diastolic blood pressures and it was found to be statistically significant as seen in Table 5 .

\begin{tabular}{|c|c|c|c|c|}
\hline \multirow{2}{*}{ Indicators } & Systolic Blood Pressure & \multicolumn{2}{c|}{$\begin{array}{c}\text { Diastolic Blood } \\
\text { Pressure }\end{array}$} \\
\cline { 2 - 5 } & r value & p value & r value & p value \\
\hline AGE & 0.101874 & 0.101874 & 0.026740 & 0.674395 \\
\hline BMI & 0.144103 & $0.022672^{*}$ & 0.181996 & $0.003904^{*}$ \\
\hline WC & 0.197988 & $0.001663^{*}$ & 0.177750 & $0.004831^{*}$ \\
\hline HC & 0.203889 & $0.001194^{*}$ & 0.226913 & $0.000298^{*}$ \\
\hline WHR & 0.082552 & 0.193560 & 0.014552 & 0.819547 \\
\hline NC & 0.194056 & $0.002061^{*}$ & 0.176716 & $0.005079^{*}$ \\
\hline SAD & 0.232101 & $0.000214^{*}$ & 0.217228 & $0.000543^{*}$ \\
\hline FBS & 0.075585 & 0.234253 & 0.089748 & 0.157354 \\
\hline TC & 0.125754 & $0.047099^{*}$ & 0.139442 & $0.027536^{*}$ \\
\hline LDL & 0.022735 & 0.720968 & 0.039582 & 0.534164 \\
\hline HDL & -0.02384 & 0.717436 & 0.024674 & 0.698705 \\
\hline TGL & 0.110723 & 0.080651 & 0.117398 & 0.064058 \\
\hline CRP & 0.239175 & $0.000135^{*}$ & 0.240154 & $0.000126^{*}$ \\
\hline Table 5: Correlation of Systolic and Diastolic Blood \\
\multicolumn{5}{|c}{ Pressures with Different Anthropometric } \\
Indicators and CRP \\
\hline
\end{tabular}

*Statistically significant

\section{DISCUSSION}

Hypertension is a major risk factor for cerebrovascular and cardiovascular diseases. The importance of body mass index, waist circumference, waist hip ratio for estimating cardiovascular disease risk has been well established by various studies. ${ }^{14,15,16,17,18,19}$ Ectopic fat accumulation in the viscera, mediastinum and epicardium might also be responsible for the concomitant increase in BP. ${ }^{20}$ Thus, the present study includes in addition to the above-mentioned variables, sagittal abdominal diameter and neck circumference as risk factors. Only few studies in India have used these as risk factors of cardiovascular diseases in rural population.

In our study, waist circumference and sagittal abdominal diameter have also been considered as indicators of coronary risk since it had high correlation with abdominal fat as seen in some other studies. ${ }^{21,22}$ Studies suggest that WC is the most widely used indicator of abdominal obesity and has also been used as a marker of increased BP.15,16 SAD has been considered as more closely related to visceral fat mass than the other anthropometric measures, because it is measured in a supine position when subcutaneous fat is moved to the sides of the waist. ${ }^{23}$

Upper body subcutaneous fat as estimated by neck circumference may confer risk above and beyond visceral abdominal fat. Anatomically, upper body SC fat is a unique fat depot located in a separate compartment compared with visceral adipose tissue. Systemic free fatty acid concentrations are primarily determined by upper body SC fat, suggesting that this fat depot may play an important role in risk factor pathogenesis. ${ }^{23}$ Studies have indicated that NC may be independent correlate of metabolic risk factors beyond BMI and waist circumference. ${ }^{24}$ Besides, NC is considered an index of upper body obesity and correlates positively with changes in systolic and diastolic blood pressure and other components of the metabolic syndrome. 22,25

The higher CRP levels are significantly correlated with higher grade of hypertension. ${ }^{26}$ Epidemiological studies support a strong relationship between CRP levels and cardiovascular risk in individuals free of cardiovascular disease at baseline. Many of the epidemiological studies that associated CRP with future cardiovascular events included patients with hypertension. ${ }^{27}$

It is seen from Table 1 that the mean values of most of the anthropometric indicators in female were higher than the cut-off values for a female, which indicate a high trend of obesity/overweight in females than males in the study population. This corresponds to the global figures, which also indicate that obesity is more common in females than males. ${ }^{28}$

From Table 2 and 3, it is evident that the number of study subjects with BMI, WC, NC and SAD above the cut-off value were higher in hypertensive males than in normotensive males indicating that they might be risk factors for hypertension in the male population and these findings are similar to some studies. ${ }^{29}$ But only SAD was significantly different in hypertensive and normotensive females. This might probably be because of a small sample of females recruited for the study.

In our study, the mean values of all the anthropometric indicators, except the waist hip ratio were significantly higher in hypertensive males than the normotensive males as seen in Table 4. This finding was similar to several studies.30,31,32,33,34 thus indicating that the anthropometric indicators used in this study are indeed risk factors for hypertension and in turn cardiovascular diseases.

But only the CRP values were significantly different 
among hypertensive and normotensive females. Rest of the variables was not significantly different in the studied female population. The probable reason might be a small sample of females who got randomly selected for the study. Further studies involving the female population would be needed before reaching a conclusion.

It is seen from Table 5 that a positive correlation between certain indicators like BMI, waist circumference, hip circumference, neck circumference, sagittal abdominal diameter, total cholesterol and CRP levels with systolic and diastolic blood pressure were found which was similar to several studies. ${ }^{35,36,37,38}$ thus indicating that these indicators are related to hypertension.

\section{CONCLUSION}

In this study CRP, SAD, HC, WC and NC showed a positive correlation with both systolic and diastolic blood pressure. This suggests that WC and SAD can be used to get information about visceral obesity in an individual and Neck circumference can be used to measure upper body obesity. This also suggests that decrease in intra-abdominal fat could decrease the blood pressure.

\section{REFERENCES}

1. Gupta R, Guptha S. Strategies for initial management of hypertension. Indian J Med Res 2010;132(5):531-42.

2. Gupta R, al-Odat NA, Gupta VP. Hypertension epidemiology in India: meta-analysis of 50 year prevalence rates and blood pressure trends. J Hum Hypertens 1996;10(7):465-72.

3. Gupta R. Trends in hypertension epidemiology in India. J Hum Hypertens 2004;18(2):73-8.

4. Ramalingam S, Chacko T. Blood pressure distribution and its association with anthropometric measurements among Asian Indian adolescents in an urban area of Tamil Nadu. Int J Med Sci Public Health 2014;3(9):11004.

5. Li HX, Zhang F, Zhao D, et al. Neck circumference as a measure of neck fat and abdominal visceral fat in Chinese adults. BMC Public Health 2014;14:311.

6. Cornier MA, Despres JP, Davis N, et al. Assessing adiposity: a scientific statement from the American Heart Association. Circulation 2011;124(18):1996-2019.

7. Riserus U, Faire U, Berglund L, et al. Sagittal abdominal diameter as a screening tool in clinical research: cutoffs for cardiometabolic risk. J Obes 2010;2010:1-7.

8. Abdullah A, Amin FA, Stoelwinder J, et al. Estimating the risk of cardiovascular disease using an obese-years metric. BMJ Open 2014;4(9):e005629.

9. Prabhakaran D, Shah P, Chaturvedi V, et al. Cardiovascular risk factor prevalence among men in a large industry of North India. The Nat Med J India 2005;18(2):59-65.

10. Seventh report of the Joint National Committee on Prevention, Detection, Evaluation and Treatment of High Blood Pressure (JNC 7). Available at: http://www.nhlbi.nih.gov/files/docs/guidelines/phycar d.pdf.

11. WHO expert Committee on Physical status: the Uses and Interpretation of Anthropometry. Physical status: the use and interpretation of anthropometry: Report of a WHO expert Committee. Geneva, Switzerland: World Health
Organization, 1995. World Health Organisation Technical Report Series 854.

12. Snehalatha C, Vishwanathan V, Ramachandran A. Cut off values for normal anthropometric variables in Asian Indian adults. Diabetes Care 2003;26(5):1380-4.

13. Preis SR, Massaro JM, Hoffman U, et al. Neck circumference as a novel measure of cardiometabolic risk: the Framingham heart study. J Clin Endocrinol Metab 2010;95(8):3701-10.

14. Wang Z, Hoy WE. Waist circumference, body mass index, hip circumference and waist to hip ratio as predictors of cardiovascular disease in aboriginal people. Eur J Clin Nutr 2004;58(6):888-93.

15. Van Dijk SB, Takken T, Prinsen EC, et al. Different anthropometric adiposity measures and their association with cardiovascular disease risk factors: a meta-analysis. Neth Heart J 2012;20(5):208-18.

16. Chen Y, Copeland WK, Vedanthan R, et al. Association between body mass index and cardiovascular disease mortality in East Asians and South Asians: pooled analysis of prospective data from the Asian Cohort Consortium. BMJ 2013:347.

17. Barbosa LS, Scala LCN, Ferreira MG. Association between anthropometric markers of body adiposity and hypertension in an adult population of Cuiaba, Mato Grosso. Rev Bras Epidemiol 2009;12(2):1-11.

18. Flint AJ, Rexrode KM, Hu FB, et al. Body mass index, waist circumference, and risk of coronary heart disease: a prospective study among men and women. Obes Res Clin Pract 2010;4(3):171-81.

19. Oliveira JS, Amorim PRS, Rosado GP, et al. Waist circumference and sagittal abdominal diameter as markers of blood pressure abnormality. J Hum Nutr Food Sci 2014;2(2):1031.

20. Alfie J, Diaz M, Paez O, et al. Relationship between neck circumference and hypertension in the national hypertension registry (the RENATA study). Rev Argen Cardiol 2012;80(4):275-9.

21. Stokic E, Srdic B, Brtka V, et al. Sagittal abdominal diameter as the anthropometric measure of cardiovascular risk. Recent advances in cardiovascular risk factors. Prof. Mehnaz Atiq (ed): 2012. Available at: http://www.intechopen.com/books/recent-advancesin-cardiovascular-risk-factors/sagittal-abdominaldiameteras-the-anthropometric-measure-ofcardiovascular-risk.

22. Turcato E, Bosello O, Di Francesco V, et al. Waist circumference and abdominal sagittal diameter as surrogates of body fat distribution in the elderly: the irrelation with cardiovascular risk factors. Int J Obes 2000;24(8):1005-10.

23. Nielson S, Guo Z, Johnson CM, et al. Splanchnic lipolysis in human obesity. J Clin Invest 2004;113(11):1582-8.

24. Liang J, Teng F, Liu X, et al. Syndergistic effects of neck circumference and metabolic risk factors on insulin resistance: the cardiometabolic rise in Chinese study. Diabetol Metab Syndr 2014;6:116.

25. Saka M, Turker $P$, Ercan $A$, et al. Is neck circumference measurement and indicator for abdominal obesity? A pilot study on Turkish adults. Afr Health Sci 2014;14(3):570-5. 
26. Kumar R, Kochhar S. C-reactive protein and severity of hypertension. JARBS 2013;5(4):331-5.

27. Kozan O, Buyukozturk K, Ilerigelan B, et al. The impact of plasma high sensitivity $C$ reactive protein levels on cardiovascular risk stratification of hypertensive patients: results of the ICEBERG study. J Clin Hypertens 2007;9(7):500-5.

28. Gupta S, Agrawal BK, Sehajpal PK, et al. Prevalence and predictors of essential hypertension in the rural population of Haryana, India: an hospital based study. J Rural Trop Public Health 2011;10:29-34.

29. Kanter R, Caballero B. Global gender disparities in obesity: a review. Adv Nutr 2012;3(4):491-8.

30. Deshmukh PR, Gupta SS, Dongre AR, et al. Relationship of anthropometric indicators with blood pressure levels in rural Wardha. Indian J Med Res 2006;123:657-64.

31. Fang F, Nie J. Study of body mass index and waist circumference in association with blood pressure in adult Guangzhou residents. Di Yi Jun Yi Da Xue Xue Boa 2003;23(8):837-40.

32. Wilsgaard T, Schirmer H, Arnesen E. Impact of body weight on blood pressure with a focus on sex differences: the tromso study, 1986-1995. Arch Intern Med 2000;160(18):2847-53.
33. Gryglewska B, Grodzicki T, Kocemba J. Obesity and blood pressure in the elderly free-living population. J Hum Hypertens 1998;12(9):645-7.

34. Zhao LC, Wu YF, Zhou BF, et al. Mean level of blood pressure and rate of hypertension among people with different levels of body mass index and waist circumference. Zhonghua Liu Xing Bing Xue Za Zhi 2003;24(6):471-5.

35. Wu HY, Chen LL, Zheng J, et al. Simple anthropometric indices in relation to cardiovascular risk factors in Chinese type 2 diabetic patients. Chin J Physiol 2007;50(3):135-42.

36. Esmaillzadeh A, Mirmiran P, Azizi F. Waist-to-hip ratio is a better screening measure for cardiovascular risk factors than other anthropometric indicators in tehranian adult men. Int J Obes Relat Metab Disord 2004;28:1325-32.

37. Kaur P, Ezhil R, Sankarasubbaiyan S, et al. A comparison of anthropometric indices for predicting hypertension and type 2 diabetes in a male industrial population of Chennai, South India. Ethn Dis 2008;18(1):31-6.

38. Ghosh JR, Bandyopadhyay AR. Comparative evaluation of obesity measures: relationship with blood pressures and hypertension. Singapore Med J 2007;48(3):232-5. 